\title{
Health Hazards, Risk and Safety Practices in Construction Sites - A Review Study
}

\author{
V. H. P. Vitharana, G. H. M. J. Subashi De Silva and Sudhira De Silva
}

\begin{abstract}
This review attempts to identify the health hazards, risks and causes of poor safety practices in construction sites. In addition, the differences in safety practices in both developed and developing countries and methods to improve construction site safety are discussed.

Effects of some health hazards are chronic while some are acute. Mostly reported acute health hazards are "workers fall from height" and "electric shocks", while mostly reported chronic health hazard is "exposure to hazardous substances".

Lack of awareness about site safety and dislike to wear Personal Protective Equipment (PPE) were identified as main causes of poor safety practices in construction sites. One of the major needs with regard to the construction industry is to enhance professionals' interests in active safety management and implementation of awareness programs, which must be developed and implemented among construction workers. Awareness on possible risk factors and knowledge on how to reduce these risk factors among workers and contractors will enhance site safety.
\end{abstract}

Key words: $\quad$ Personal Protective Equipment (PPE), Site management, Workers.

\section{Introduction}

Construction site is a very important place, as a considerable number of workers are involved in construction activities. Employments in construction site can be categorized into three groups; "Management and technical" work force, "Skilled" work force and "Semi-skilled and Unskilled" work force. Personnel with high educational qualifications, usually graduates, trained to design, manage and instruct the construction processes can generally be identified as "Management and technical" work force. Persons who possess extensive knowledge and experience in their construction activities or profession are identified as "Skilled" work force. "Semi-skilled and Unskilled" work forces are the site labourers with little or no construction knowledge. Generally, all skilled, semi-skilled and unskilled workers are at risk of being injured, death or various illnesses in a construction site, although the level of risk varies with activities they are engaged in.

A hazard is a potential source of harm or an adverse health effect on a person or persons. "Hazard" and "Risk "are often used interchangeably. Workers of construction sites are, generally, exposed to an excessive risk of being injured at work (Almenet al. [4]). Pungvongsanuraks et al[28] elicited that construction industry is unique and complex compared with other industries and it contains a wide range of construction materials and products, building services, manufactures, contractors, sub-contractors, design, operation, and refurbishment services. These complexities make the construction industry as one of the most hazardous industries that causes high rate of accidents.

Safety in construction sites is needed to be highly considered in order to reduce the risk of being injured at work. Safety is also identified as one of the major factors affecting the image of the project manager and the organization (Grandjean. [36]). "Safety, health and welfare on construction sites", the training manual published by the International Labour Office in Geneva[37],states that high rate of accidents occurs in the construction industry than in the other manufacturing sector. This is

V.H.P.Vitharana, B.Sc.Physics(Hons)(Ruhuna), Research (Mphil)Student, Department of Civil and Environmental Engineering, Faculty of Engineering, University of Ruhuna, Sri Lanka.

Eng. (Dr.) (Mrs.) G.H.M.J. Subashi De Silva, PhD (Saitama), B.Sc.Eng. (Hons)(Moratuwa), C.Eng. MIE (Sri Lanka), Senior Lecturer, Department of Civil and Environmental Engineering, Faculty of Engineering, University of Ruhuna, Sri Lanka.

Eng. (Dr.) Sudhira De Silva, PhD (Saitama), M.Eng (Saitama) B.Sc.Eng. (Hons)(Moratuwa), C.Eng. MIE (Sri Lanka), Senior Lecturer, Department of Civil and Environmental Engineering, Faculty of Engineering, University of Ruhuna, Sri Lanka. 
possibly because the construction industry consists of high self-employed workers, and large number of seasonal and migrant workers; many of them are unfamiliar with construction processes. In addition, those workers are exposed to bad weather and involved in many different trades and occupations. However, the manual published by International Labour Office in Geneva [37] stated that, "The concerned work should be safe and conditions on the construction site should not cause damage to life, health and professional skills". Further, it[37] explains that employer needs to have safety norms and health standards; there should be safety practices in construction sites to be followed by the employer. Effective safety management is to make the environment safe, to make the job safe and to make workers safety conscious. In recent years, many developed countries have considered safety as one of the important management issues of construction projects, especially, personal safety (Chen et al[7]).

Objective of this study is to review previous research studies on investigation of health hazards and risks in construction sites to identify causes of poor safety practices and methods for improving construction site safety.

\section{Methodology}

The articles, which had "construction safety, health hazards" as keywords in research papers, were identified. These papers have been published in journals, conference proceedings and technical reports in the respective official websites. Out of 200 articles, only thirty-seven articles were selected and reviewed, in order to identify the health hazards and risks in construction sites, causes of lacking safety practices and possible methods to improve safety in construction sites.

\section{Health risks, poor safety practices and methods to improve site safety}

Health hazards and risk factors associated with construction activities, identified from previous studies, are presented in this section. In addition, causes of poor safety practices and possible methods to enhance safety practices were also identified.

\subsection{Health hazards and risks}

A hazard is a potential source of harm or an adverse health effect on persons. Risk is the likelihood that a person may be harmed or suffered from adverse health effects if exposed to a hazard. Therefore, risk can be minimized, although the hazard is there.

Two major hazards that are common in construction sites have been identified by Abdul et al [21]. Physical injury hazards are often caused by equipment used such as scaffolds, power access equipment, ladders, plant and machinery for excavation and processes such as manual handling, and roof work (Abdul et al [21]). These hazards can cause direct injury to workers at site and, if severe, it can even cause death. Different types of mechanical energy such as noise, vibration, radiation and temperature extremes (i.e. hot and cold) can also cause physical injury hazards. Noise is inevitable in construction sites due to the nature of construction activities. However, in a previous study (Archer [33]) construction noise has been identified as one of the risks, which can cause hearing loss (one of the adverse health effects). Chemical hazards found in construction work include asbestos, welding fumes, spray paints, cutting oil mists, solvents and hexavalent chromium (Pendleburyet al [17]). Construction workers consider dust as the major chemical hazard. In addition, workers consider asbestos, cement and adhesives or solvents, to be the materials that can adversely affect their health.

Effects of some health hazards are chronic while some are acute, as categorised in Table 1. Chronic effects usually develop slowly, and shall cause sickness or death after a certain period. For example, if a worker breathes small amounts of asbestos fibres, he may not notice the effect of that, because there are no acute effects. However, if the worker inhales small amount of asbestos fibres for a prolonged time, the chances of getting asbestos related diseases (i.e., a lung cancer) will increase. Workers neglect the health hazards having chronic effects. Mostly reported chronic health hazards is "exposure to hazardous substances" (Table 1).Further, chronic health hazards include exposure to corrosive materials, skin sanitizers and irritants, (Table 1) that were also identified as risk factors in several previous studies. 
Table 1 - Health hazards identified in previous studies

\begin{tabular}{|c|c|c|c|c|c|c|c|c|c|}
\hline \multicolumn{2}{|r|}{ Health hazards } & A & B & $\mathrm{C}$ & D & E & $\mathbf{F}$ & G & $\mathbf{H}$ \\
\hline \multirow{12}{*}{ 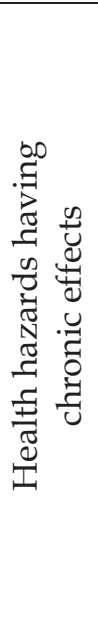 } & $\begin{array}{l}\text { Physical hazards (Noise, Heat, Humidity, Solar Radiation, } \\
\text { Radiation from nuclear power plants) }\end{array}$ & $x$ & $\times$ & & & & & & \\
\hline & Asbestos (insulation board, ceiling tiles, pipe lagging) & & $\times$ & & & & & & \\
\hline & Ionizing radiation (welding) & & $\times$ & & & & & & \\
\hline & Corrosive materials (Concrete, brick acid) & & $\times$ & & $\times$ & & & & \\
\hline & Skin sanitizers, irritants(Bitumen, acids, alkalis, cement) & & $\times$ & & $\times$ & & & & \\
\hline & $\begin{array}{l}\text { Contaminated land and materials(Old buildings, redundant } \\
\text { gas works) }\end{array}$ & & $\times$ & & & & & & \\
\hline & Hazardous substances & $x$ & $\times$ & $x$ & & & & & \\
\hline & Vibratory tools & & $\times$ & & & & & & \\
\hline & Sewage (Dirty water) & & $\times$ & & & & & & \\
\hline & Compressed air environment (Sewers and tunnels) & & $\times$ & & & & & & \\
\hline & Environmental with limited lighting(tunnelling) & & $\times$ & & & & & & \\
\hline & Improper housekeeping & & & & $\times$ & & & & \\
\hline \multirow{10}{*}{ 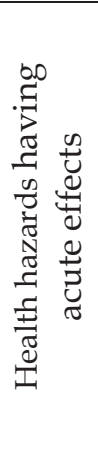 } & Ladder & $\times$ & & $x$ & & & & & \\
\hline & Roof work & $x$ & & $x$ & & & & & \\
\hline & Lifting, carrying or moving heavy tools or materials & & $\times$ & & & & $\times$ & & \\
\hline & Harmful chemicals & & $\times$ & & & & $\times$ & & \\
\hline & Plant and machinery, tool usage & $x$ & & & & & $\times$ & & \\
\hline & Fire and emergency & $x$ & & & & & & & \\
\hline & Excavating in deep trenches & & & & $\times$ & & & & \\
\hline & Workers fall from height & & & & $x$ & & $\times$ & $\times$ & $\times$ \\
\hline & Electric shocks & & & $\times$ & & $x$ & $\times$ & & \\
\hline & Protective clothing & $x$ & & & & & & & \\
\hline
\end{tabular}

Workers, who are being exposed to vibration, noise and many other hazards, also face with chronic health effects, although they are often not aware of them. Work-related back pain, work-related upper limb disorder, hand-arm vibration syndrome, work-related dermatitis, respiratory diseases, skin sanitizers, pneumoconiosis-Asbestos, pneumoconiosisSilicosis, radiation diseases (ionizing radiation), heat stress, ultraviolet radiation, hyperbaric risks and decompression illness are common health problems among construction workers (Pendleburyet al,[17]).

Mostly reported health hazards having acute effects are "workers fall from height", and "electric shocks". In addition, ladder, roof work, lifting, carrying or moving heavy tools or materials, harmful chemicals, plant and machinery, tool usage, fire and emergency excavating in deep trenches and protective clothing, that were identified as risk factors in several previous studies, can be considered as health hazards having acute effects (Table 1).

Workers considered working in high levels as the principal construction risk activity (Table
1). Scaffolds contribute towards the accident occurrences at the construction workplace (Ismail and Ghani, [12]). In general, injury may lead by three dependant levels: near miss, incident and accident. Collapsing of a scaffold is an "incident" in the construction sites. If there are no injuries and damages to workers because of collapsing of the scaffold, it is introduced as "near miss" and if the incidents lead to injury or damage it is called as an "accident". "Risk and hazard are allocated in first level which means near miss, therefore, no on-time identification of hazard and risk causes to create incident and preventing accident in incident stage is unavoidable"(Charehzehi and Ahankoob [6]).

\subsection{Causes of poor safety practices}

Possible causes of poor safety practices, that were identified from previous studies are summarised in Table 2.The identified possible causes of poor safety practices can be categorized into safety equipment, safety management, safety attitude of workers, safety training and others. 
Table 2 - Possible causes of poor safety practices

\begin{tabular}{|c|c|c|c|c|c|c|c|c|c|c|c|c|c|c|c|c|c|}
\hline & Causes of Poor Safety Practices & A & B & C & D & $\mathbf{E}$ & $\mathbf{F}$ & G & $\mathbf{H}$ & I & J & $\mathbf{K}$ & $\mathbf{L}$ & $\mathbf{M}$ & $\mathbf{N}$ & $\mathrm{O}$ & $\mathbf{P}$ \\
\hline$>\stackrel{\text { 苞 }}{0}$ & $\begin{array}{l}\text { Dislike to wearing PPE by unskilled } \\
\text { labourers }\end{array}$ & $\times$ & & $x$ & $x$ & & & & & & & & & $x$ & $x$ & & \\
\hline 䒕 & Unavailability of PPE & & & $x$ & & & & & & & & & & & & & \\
\hline & $\begin{array}{l}\text { Low level of awareness on using } \\
\text { PPE }\end{array}$ & & & $x$ & & & & & & $\times$ & & & & & & $x$ & \\
\hline 苞蒫 & $\begin{array}{l}\text { Poor safety awareness of project } \\
\text { managers }\end{array}$ & & & & & & & & & & & $x$ & $\times$ & & & & \\
\hline అ & Failure to appoint a safety officer & & & & & & & & $x$ & & $x$ & & & & $x$ & & \\
\hline 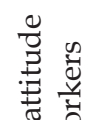 & $\begin{array}{l}\text { Lack of awareness about site safety } \\
\text { and regulations }\end{array}$ & $x$ & & & & & & & & & & & $\times$ & & & & \\
\hline 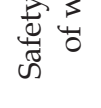 & $\begin{array}{l}\text { No willingness to follow safety } \\
\text { norms }\end{array}$ & & & $\times$ & & & & $\times$ & & & & & & & & & \\
\hline$\Rightarrow 00$ & Lack of training facilities & & & & & & $\times$ & & & & & & & & & & $x$ \\
\hline$\tilde{\oplus}$ & Lack of understanding the job & & & $x$ & & & & & & & & & & & & & \\
\hline & Falls & $x$ & $x$ & & & & & & & & & & & & & & \\
\hline$\frac{\dot{\Xi}}{\tilde{\Xi}}$ & $\begin{array}{l}\text { Unsafe behaviour such as Operating } \\
\text { without authority, Working with } \\
\text { moving machinery, Wearing } \\
\text { dangling clothes and unsafe lifting }\end{array}$ & & & & & $\times$ & & & & & & & & & & & \\
\hline & $\begin{array}{l}\text { Workers under the influence of } \\
\text { alcohol and drugs }\end{array}$ & & & $\times$ & & & & & & & & & & & & & \\
\hline ARame & deenet al [18] Sri Lanka, BPendleburyet al [17] & & & & & & & & & & & & & & & & \\
\hline $\begin{array}{l}\text { DSoma } \\
\text { Antonic } \\
\text { Malaysi } \\
\text { Vithara }\end{array}$ & $\begin{array}{l}\text { Indaraswaranet.al [29] Sri Lanka, E Ahamade } \\
\text { t al [3] Spain, H Jeyakanthanand Ahamad [27] } \\
\text { K Shibani et al [19] United Arab Emirates,, } \\
\text { et al [30] Sri Lanka ,O Jackson et al [13] Denma }\end{array}$ & 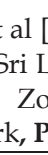 & & & nka, & & & & er & & & 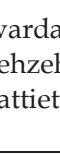 & & & . & & $\begin{array}{l}\mathbf{G} \\
{[6]} \\
\mathbf{N}\end{array}$ \\
\hline
\end{tabular}

"Dislike to wear Personal Protective Equipment (PPE)", which are categorized under "Safety equipment", is often identified as the cause of poor safety practices (Table 2). In addition, "Low level of awareness toward using PPE" was also frequently identified as a possible cause of poor safety practices. This was identified, possibly, because unskilled workers, who have less educational levels, were found to be over presented among accident victims (Rameezdeen et al [18]). Unavailability of PPE also contributes to poor safety practices. In a study by Ahamadet al [22], it has been found that hardhats are often used in construction sites and safety boots are occasionally used. However, Hi-Viz jackets are rarely used in construction sites. Safety gloves, earplugs and safety glasses are also very rarely used in construction sites. Availability of PPE was studied by Tam et al [20] and most commonly provided PPE were identified as gloves, hard hats and eye goggles, although many workers consider that hard hats are not convenient for their operations. However, Jackson et al [13] have elicited that wearing PPE and awareness of surrounding as the most common suggestion to prevent critical accidents.

Failure to appoint a safety officer was often identified as a cause of scarcity of site safety (Table 2). However, effects of "Safety attitude of workers" and "Safety training" have not often been studied, although "no willingness to follow safety norms" by workers was identified as a cause of poor safety practices.

Tam et al [20] showed that in the construction industry, workers have high mobility and they switch from one organisation to another, frequently. The transient nature of the construction workforce makes it difficult to train workers. However, availability of trained or 
skilled workers directly contributes to the improvement of quality of construction work, and indirectly contributes to improve the site safety. It has been suggested by Gunawardana and Jayawardane [26] that providing good training facilities for workers would help to retain skilled work force in construction sites. This might be a possible solution to sustain a skilled work force on a long-term basis in construction sites compared to the other industries. Further, Tam et al[20] found that 24\% of contractors provide systematic training on safety for the first line workers, $65 \%$ of contractors offer occasional training, $11 \%$ of contractors provide training very rarely. It seems, in China, many organizations provide occasional training on site safety to workers.

A survey, similar to Ahamedet al [22], has been conducted to explore the status of construction safety management, by Tam et al [20]. 62\% of the construction organisations do not have documented safety manuals. However, all the respondents(safety representatives in construction organisations who participated in the survey) had documented procedures for safety management on construction sites. In this study, it has been reported that majority of workers are not aware of safety manual. Nevertheless, others are in the opinion that safety issues are discussed and presented at other meetings, such as construction progress meetings.

Site management seemed to be non-interested in emphasizing the need of personnel safety practices among their workers (Ahamadet al, [22]), although this might not be very common in nowadays. In some cases, safety is considered as part of Total Quality Management (TQM) (Husin et al, [11]). In addition, Hassana et al [10] have revealed that good organizational commitment and communication are highly associated with effective accident reporting, high line management commitment and active personal role. Active personal role to safety and health resulted in greater influence among workmates, and low obstacles to safety behaviour according to the Hassana et al [10].

Farooqui et al [24] have found that, workers and other staff members are sometimes under the influence of alcohol, and drugs possibly because they are not tested for drugs and alcohol before starting and during activities in the construction sites (Table 2). However, these previous studies were limited to collecting opinions of professionals, based on their experience related to accidents at building construction sites. Workers' views on causes for accidents will also be helpful to enhance safety practices in construction sites.

\subsection{Possible methods to improve construction site safety}

Managing a project succesfully means not just executing it according to specifications within the stipulated time and with budgeted funds but also with optimum safety (Belel and Muhmud[5]). In addition, it has been stated that, "enhancing safety performance in construction site is not easy but possible" (Charehzehi and Ahankoob [6]).Possible methods to improve construction safety were identified by reviewing previous studies and are summarised in Table 3.

The mostly suggested method to improve construction safety is related to "Safety management" (Table3). Nevertheless, most of the identified poor causes of construction safety are categorized under "Safety equipment". This suggests that safety management at the organisational level can improve organisational performance as stated by Agwa et al [2]. In addition, one of the essential steps for safetymanagement in construction sites is hazard identification, since the most unmanageable risks are from unidentified hazards (Zolfagharian et al [32]).

To improve site safety, contractors in construction sites are advised to, have an organizational safety policy for the proper administration of safety, provide formal safety training for their workers and conduct daily "toolbox" safety talks. In addition, they are advised to conduct weekly formal safety meetings at the project level, always secure safety protection measures at the job site, always provide PPE to their workers, post safety signs and posters at the job site, conduct weekly safety inspections, reward workers for their safe behaviour, personalize workers for their unsafe behaviour, encourage workers to make use of secure equipment and reduce labour turnover rates less than $25 \%$ (El-Mashaleh et al, [9]).

Mahalingam and Raymond [16] have identified using coercive enforcement mechanisms such as fines, as one of the most successful strategies used on projects to improve safety performance (Table 3).

The important attitudes for increasing safety performance and declining risk are to identify root causes of construction hazards and accidents, and manipulating proper precautionary tools and equipment related to the type of construction project and site condition (Charezehi and Ahankoob[6])(Table 3). 
Table 3 - Possible methods to improve construction site safety

\begin{tabular}{|c|c|c|c|c|c|c|c|c|}
\hline \multicolumn{2}{|r|}{ Possible methods to improve construction site safety } & A & $\mathrm{B}$ & $\mathrm{C}$ & $\mathrm{D}$ & $\mathrm{E}$ & $\mathrm{F}$ & G \\
\hline 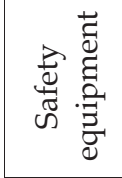 & Providing PPE to their workers always & $x$ & & & & & & \\
\hline \multirow{9}{*}{ 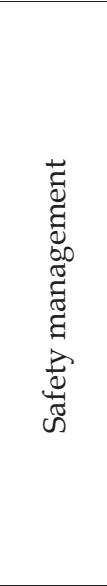 } & Creating safety regulations and policies & $x$ & $\times$ & & & & & \\
\hline & Identifying Hazards & & $\times$ & & & & & \\
\hline & Asses and evaluate risk & & $\times$ & & & & & \\
\hline & Decide precautions & & $\times$ & & & & & \\
\hline & $\begin{array}{l}\text { Recording findings and updating in relation to the work } \\
\text { condition }\end{array}$ & & $x$ & & & & & \\
\hline & $\begin{array}{l}\text { Plan out short and long term safety budgets to ensure the } \\
\text { adequacy of safety implementation on site }\end{array}$ & & & & $\times$ & & & \\
\hline & Safety on site should be discussed at management meetings & & & & & $\times$ & & \\
\hline & $\begin{array}{l}\text { Implementation of total safety management at the } \\
\text { organisational level in construction companies }\end{array}$ & & & & & & $\times$ & \\
\hline & Using coercive enforcement mechanisms such as fines & & & $\times$ & & & & \\
\hline \multirow{2}{*}{ 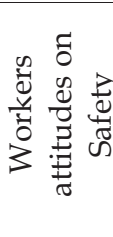 } & $\begin{array}{l}\text { Construction workers must identify unsafe conditions and } \\
\text { behaviors and try to correct them }\end{array}$ & & & & & $\times$ & & \\
\hline & $\begin{array}{l}\text { Increasing in workers awareness of risk factors will be useful } \\
\text { to increase the productivity and reduce the risk associated } \\
\text { with construction activities }\end{array}$ & & & & & & & $x$ \\
\hline \multirow{4}{*}{ 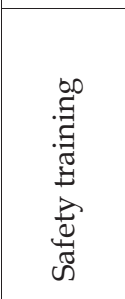 } & Incentive programs should be developed & & & & & $x$ & & \\
\hline & $\begin{array}{l}\text { Ensure that a very new employee on project site is given an } \\
\text { appropriate orientation regarding safety and safety } \\
\text { inspections }\end{array}$ & & & & & $\times$ & & \\
\hline & Conduct weekly safety inspection & $\times$ & & & & & & \\
\hline & Conduct weekly formal safety meetings at the project level & $\times$ & & & & & & \\
\hline$\frac{\ddot{\Xi}}{\stackrel{5}{0}}$ & Reduce labour turnover rates to less than $25 \%$ & $x$ & & & & & & \\
\hline
\end{tabular}

A El-Mashaleh et al [9] Jordan, BCharezehi and Ahankoob[6] Malaysia, CMahalingam and Raymond [16] India,

DChia-Kung Lee and Jaafar [23] China, EBelel and Muhmud [5] Nigeria, FAgwa et al [2]Nigeria, GVitharana et al [30]Sri Lanka

They have introduced a continuous safety development process that includes six steps: creating safety regulations, identify hazard, asses and evaluate risk, decide precaution, record findings and updating in relation to the work condition. Safety inspection is the most important factor that influences safety performance on sites (Chia-Kung Lee and Jaafar, [23]). Safety on site should be discussed at management meetings and safety recognition and incentive programs should be developed (Belel and Muhmud[5]). However, Chenet al, [8] have identified public works managers and design and audit managers have lower level of perceived safety than contractor managers do (Chen et al, [8])(Table 3). Reinforcing the perception of safety between these two types of construction personnel is important to reduce construction accidents (Chen et al, [8]).

It is utmost important to ensure that a very new employee on project site is given an appropriate orientation regarding safety and safety inspections (Belel and Muhmud[5]). It is the responsibility of every construction worker to identify unsafe conditions and behaviors and try to correct them too (Belel and Muhmud[5]).

\section{Discussion}

By comparing health hazards, in different studies, it can be seen that health hazards having acute effects such as workers fall from height, have been reported more frequently 
(Section 3.1, Table 1). It was reported that 1107 major injuries are due to falling from a height according to the Health and Safety Statistics Highlights for the time period 20032004(Pendleburyet al [17]). It has been estimated that reoccurring musculoskeletal injuries range from 30,000 to 50,000 , respiratory diseases affect up to 20,000 construction workers and skin diseases affect up to 10,000 workers every year (Pendleburyet al [17]). However, in studies, especially conducted in countries like Pakistan, Sri Lanka and Malaysia, musculoskeletal injuries, respiratory diseases and skin diseases among construction workers were not reported. This does not imply that the workers in these countries did not suffer with these chronic effects. It seems that construction sites in developed countries pay their attention to both acute and chronic health effects of construction workers. The research study, which aims to identify challenges that international contractors face, when, attempting to transfer techniques to developing countries on short-term global projects, also found that contractors of these countries have different cultural perceptions of acceptable level of safety (Mahalingam and Raymond, [16]).

Many of acute effects identified in previous studies include falls in construction sites (Section 3.1, Table 1). Possible causes of these hazards might be unclear walkways and risky slips, trips and falls. Generally, workers walk in the site, by carrying things. Therefore, the worker may not be able to balance the body and difficult to see things in the site. Uncovered holes or trenches in the site might also be a cause for slips and falls in construction sites as workers carrying things cannot see such obstacles. Therefore, keeping clean pathways in construction sites will help to reduce injuries and improve the efficiency of workers. Keeping the site clean with the help of workers could be one of the responsibilities of site supervisor. Wearing boots will also help to prevent some injuries although many workers wear thin-soled athletic shoes. Contractors are suggested to give a site plan to safe access to the site, provide fences to keep the unauthorized persons away, display warning signs, declare proper walking and vehicle paths to lead safe access to working places, keep the site tidy and clean to avoid disease, similar to the recommendations made by Ahamadet al [22].
It appears that noise and vibrations are risk factors which are having chronic effects on the health of workers, but the workers are not much aware of them (Table 1). However, construction workers are exposed to a combination of noise and vibration, which are inevitable in construction sites. Exposure levels of construction workers to noise and vibration are generally high. Negative effects of noise and vibration on construction workers have been reported in previous studies. However, noise and vibration have been identified as construction hazards by $11 \%$ and $3 \%$ of workers, respectively (Pendleburyet al [17]).

Depending on the type of construction sites, workers may get exposed to noise induced by one or more sources. It addition, it was found that type and size of the work sites are important factors in noise level: large sites, generally, have high exposure levels (Department of Environmental and Occupational Health Sciences, [34]). Nevertheless, Hassan et al [10] reveal that large projects show a high and consistent level in safety while small projects show a low and varied safety levels. The report (Department of Environmental and Occupational Health Sciences, [35]), mentioned that repeated exposure to noise levels about $85 \mathrm{dBA}$ (such as years of working around construction noise without hearing protection) or exposing above $140 \mathrm{dBA}$ for a short time period, such as 1 second, can damage nerves in the inner ear, resulting in permanent and in reversible hearing loss. Construction workers in Washington states are five times more likely to request workers' compensation claims for hearing loss than workers in all occupations (Department of Environmental and Occupational Health Sciences [35]).

Vibration induced from construction machines may affect on major part of the worker's body or only a particular organ to vibrate. In Whole Body Vibration (WBV), energy enters the body through a seat or the floor; it affects the entire body or a number of organs in the body (Griffin [1]). The symptoms of WBV are not so readily recognizable and are often mistaken for other unrelated conditions. These results in hyperventilation, increased heart rate, oxygen intake, pulmonary ventilation and respiratory rate.

Causes of poor safety in construction sites have often been determined (Table 2). Improving of knowledge of construction personnel's safety 
cognition might be important in improving safety performance. Mostly identified poor safety practices are categorized under Safety equipment (Table2). To develop the knowledge on Personal Protective Equipment (PPE) and risk factors in construction sites, awareness campaigns, through many methods like "on site safety charts, displaying pictures, posters or films", can be used. In addition, practical demonstrations on site, arrangement of appropriate forms of formal or informal education and training programs for the workers on the site can be recommended, although the workers' participation in such programs would be totally dependent on their interest. Incentives on completion of such trainings would be a good process to enhance workers' interest. It would be better to introduce a system to evaluate the attitude towards safety implementation plan of project construction firms before giving them a contract. Contractors' top management should formulate strategies and develop policies to create a safe culture as a catalyst for maintaining a safe project, while considering construction needs to be completed within the given period at a given cost. Designing for safety has also been identified as viable and needed intervention to improve safety performances.

Highly recommended possible methods of construction safety are related to safety management (Table 3). Annual safety audit programs can be suggested, possibly, conducted by relevant authority, to ensure safety practices in construction sites. The scope of the audits may include the safety management system of the construction firms, labour protection measures, safety pitfalls in construction sites. Appointing full time safety officers would also be a good approach to establish safety practices among construction workers, although it is not the usual practice in construction sites in most developing countries. However, in China, in construction sites having 50 workers or more, main contractor has to nominate a full-time safety inspector; for sites with an area exceeding 10,000 $\mathrm{m}^{2}$ there must be 2-3 safety inspectors; wherever the site exceeds $50,000 \mathrm{~m}^{2}$, the main contractor has to establish a safety management team. In addition, to improve safety, engineers, architects and technical officers should be exposed to construction site safety as a part of their educational programs in a university or a technical college. Conducting workshops in safety practices for workers in construction sites will help to make them aware about safety practices associated with their activities. In addition, contractors may look into possible methods to reduce hazardous exposure, in their sites leading to both acute and chronic health diseases.

Most of the previous studies were based on survey among professionals or statistical data collected from authorities, while few studies were based on interviews and questionnaire surveys. However, it will be better to visit construction sites and get views of range of workers (i.e., skilled workers, semi skilled workers and unskilled workers) in order to find effective methods to improve site safety and to reduce risk. A comprehensive research study based on face-to-face interviews and questionnaire surveys among construction workers is required, to understand whether skilled, semi skilled and unskilled workers have an idea about risk factors and safety practices.

\section{Conclusions}

This review attempts to identify health hazards, risks and causes of poor safety practices in construction sites. In addition, the differences in safety practices in both developed and developing countries and methods to improve construction site safety are discussed.

Health hazards in construction sites can be categorised into two: acute health hazards and chronic health hazards. Mostly reported acute health hazards are "workers fall from height" and "electric shocks", while mostly reported chronic health hazard is "exposure to hazardous substances". Lack of awareness about site safety or dislike to wear Personal Protective Equipment (PPE) was identified as one of the main causes for scarcity of safety practices in construction sites. Other causes of poor safety practices include "Lack of productivity after lunch", "lack of training facilities", "lack of effective labour training (possibly due to the transient nature of the construction work force),"lack of understanding of the job", "unsafe behaviour found at industry (working with moving machinery, wearing dangling clothes, unsafe lifting, carrying and placing), "financial difficulties" and "influence of alcohol and drugs". Workers' and contractors' awareness on possible risk factors and site safety were 
more concentrated in studies in developed countries compared with developing countries.

There is no systematic study on the chronic effects of health hazards on construction workers, although possible risks were reported in some studies, implying that less attention has been paid for chronic health effects of workers. Noise and vibration associated with construction activities may have chronic effects on the health of workers.

To enhance safety practices, one of the major needs in the construction industry is to enhance professionals' interests in active safety management and implementation of awareness programs, which must be developed and implemented among construction workers. An additional training for the workers, which could be provided by contractors about equipment they use, before workers engage in their duty, would also help to prevent accidents. Awareness on possible risk factors and knowledge on how to reduce these risk factors among workers and contractors will enhance site safety.

\section{Acknowledgement}

The authors wish to express their special thanks to Transforming University of Ruhuna into International Status (TURIS) project (grant no (RU/DVC/Pro 142) for providing necessary funds to carry out this research work.

\section{References}

[1] Griffin, M. J., (1996), Hand book of Human Vibration, Elsevier Science Publishing Co Inc.

[2] Agwa, M. O., MNIM and MNISP (2012), Total Safety Management: A Strategy for Improving Organisational Performance in Selected Construction Companies in Nigeria, International Journal of Business and Social Science, Vol. 3.

[3]Antonio, L. A, Juan, C. R, and Gribb, A., (2012), Analysis of Construction Accidents in Spain 2003-2008, Journal of Safety Research, Vol.43 (5-6) 2012, pp 381388.

[4] Almen, L., Larsson, T. J., and Thunqvist, E. (2012), "The Influence of the Designer on the Risk of falling from Heights and of Exposure to Excessive workloads on Two Construction Sites", Safety Science Monitor, Vol. 16, Article 6.

[5] Belel, Z. A., and Muhmud, H., (2012), Safety Culture of Nigerian Construction Workers- A Case Study of Yola, International Journal of Scientific\& Engineering Research volume 3, Issue 9.

[6]Charehzehi, A., and Ahankoob, A., (2012), "Enhancement of Safety Performance at Construction
Site", International Journal of Advances in Engineering \& Technology, Vol. 5, Issue 1, pp 303312.

[7] Chen, W. T., Lu, C. S. and Huang, Y., H00000. (2011), Investigating the Safety cognition of Taiwan's Construction personnel, Journal of Marine Science and Technology, Vol. 19, No.4, pp 398-408.

[8] Chen, W. T., Lu, C. S. and Wang, M. (2013), Measuring the Perception of Safety among Taiwan Construction Managers, Journal of civil engineering and management, Vol. 19(1), pp 37-48.

[9] El-Mashaleh, M. S., Al-Smadi' B. M., Hyari and K. H., Rbabeh, S.M.(2010), Safety managemant in the Jordian construction industry, Jordan journal of civil engineering, Vol. 4, No.1.

[10] Hassan, C. R. C., Obasha, O. J. and Hanafi, W. H. W., (2007), Perception of Building Construction Workers towards Safety, Journal of Health and Environment, Vol. 2, No. 3, pp 271-279.

[11] Husin, H. N., Adnan, H., and Jusoff, K., (2008), Management of Safety of Quality Construction, Journal of Sustainable Development, Vol. 1, No. 3, pp 41-47.

[12] Ismail, H. B., and Ghani, K. D. A., (2012), Potential Hazards at the Construction Workplace due to Temporary Structures, Procedia - Social and Behavioral Sciences, Vol. 49, pp 168-174.

[13] Jackson, T. S., Artis, S., Hunng, Y. H., Kim, H. N., Hughes, C., Kleiner, B. and Nolden, A. (2011), "Safety Critical Incidents among Small Construction Contractors: A Prospective Case Study", The Open Occupational Health \& Safety Journal, Vol.3, pp 3947.

[14] Kaskutas, V., Dale, A. M., Nolan, J., Patterson, D., Lipscomb, H. J. and Evanoff, B. (2009), "Fall Hazard Control observed on Residential Construction Sites", American Journal of Industrial Medicine, pp 491-499.

[15] Kun Hu, Rahmandad, H., Smith-Jackson, T. and Winchester, W.(2011), "Factors Influencing the Risk of Falls in the Construction Industry: A Revies of the Evidence", Journal of Construction Management and Economics, Vol. 29, Issue 4.

[16] Mahalingam, A. and Raymond, E. (2007), Safety Issues on Global Projects, Journal of Construction Engineering and Managemant, pp 506-516.

[17] Pendlebury, M. C., Brace, C. L. and Gibb, A. G. F., (2006), Construction Health: Site Hazards and Risks, The Future of Sustainable Construction.

[18] Rameezdeen, R., Pathirage, C. and Weerasooriya, S. (2003), Study of Construction Accidents in Sri Lanka, Built-Environment-Sri Lanka, Vol. 04, no. 01:2003.

[19] Shibani, A., Saidani, M. and Alhajeri, M. (2013), Health and Safety Influence on the Construction Project Performance in United Arab Emirates (UAE), Journal of Civil Engineering and Construction Technology, Vol. 4(2), pp 32-44.

[20] Tam, C. M., Zeng, S. X., and Deng, Z. M. (2004), Identifying Elements of Poor Construction Safety Management in China, Safety Science, Vol.42( 7),pp 569-586.

[21] Abdul Hamid, A. R., Wan Yusuf, W. Z. and Singh, B., (2003), Hazards at Construction ites, 
Proceeding of the 5th Asia-Pacific Strutural Engineering and Construction Conference, Johor Bahru.

[22] Ahamed, M., Nafeel, A., Rishath, A., and Dissanayake, P., (2011), Site Safety of Sri Lankan Building Constrction Industry, Proceedings of the International Conference on Structural Engineering, Construction and Management (ICSECM), Kandy, Sri Lanka, 15-17 December 2011.

[23] Chia- Kung Lee and Jaafar' Y., (2012), Prioritization of Factors Influencing Safety Performance on Construction Sites: A Study based on Grade Seven (G7) Main Contractors' Perspectives, International conference on Business, Management and Governance (ICBMG 2012), Hong Kong.

[24] Farooqui, R. U., Arif, F. and Rafeeqi, S. F. A. (2008), Safety Performance in Construction Industry of Pakisatan, in First International Conference on Construction in Developing Countries, Karachi, Pakistan.

[25] Galappatti, L. L., Subashi De Silva, G. H. M. J. and Sudhira De Silva, (2013), "Investigation on Methods to Improve Helath and Safety Practices in Construction Sites", Special Session on Structural Solid Mechanics, $4^{\text {th }}$ Interantional Conference on Structural Engineering and Construction Management, Kandy, Sri Lanka.

[26] Gunawardana, N. D., and Jayawardane, A. K. W., (2003), The Training needs of Construction Workers in Sri Lanka, Proceedings of Annual Sessions of IESL, Oct. 2001.

[27] Jeyakanthan, J. and Ahamad, Z. (2012), Causes and Effects of Accidents in Building Construction Industry in Sri Lanka", Proceedins of the 2nd Annual Sessions of the Society of Structural Engineers-Sri Lanka.

[28] Pungvongsanuraks, P., Thitipoomdacha, C., Teyateeti, S. and Chinda, T. (2010), "Exploratory Factor Analysis of Safety Culture in Thai Construction Industry", Proceedings of the 2010 International Conference on Engineering, Project and Production Management.

[29] Somasundaraswaran, A. K., Brammananda, T., Akeel, J. A., and Rajakumar, G., (2006), Evaluation of Safety Level at Construction Sites in Sri Lanka, Proceedings of the third Academic Sessions, University of Ruhuna.

[30] Vitharana, V. H. P., Subashi De Silva, G. H. M. J. and Sudhira De Silva (2013), Workers Awareness of Risk Factors and Safety Practices in Construction Sites, Third Annual Session of Society of Structural Engineers in Sri Lanka, Colombo.

[31] Zhao, D., Lucus, J. and Thabet, W., (2009), "Using Virtual Environments to Support Electrical Safety Awareness in Construction", Proceedings of the 2009 Winter Simulation Conference.

[32] Zolfagharian, S., Ressang, A., Irizarry, J., Nourbakhsh, M. and Zin, R. M., (2011), Risk Assessment of Common Construction Hazards among Different Countries, Sixth International Conference on Construction in the $21^{\text {st }}$ Century, Kuala Lumpur, Malaysia.
[33] Archer, D. W., Whole body vibration: Causes, Effects and Cures, Report published by the National Association of Professional Inspectors and Testers, United Kingdom.

[34] Department of Environmental and Occupational Health Sciences, Construction Industry Noise Exposures, Brick layers, Technical Report, published by School of Public Health and community Medicine, University of Washington.

[35] Department of Environmental and Occupational Health Sciences, Construction Industry Noise Exposures, Construction workers, Technical Report published by, School of Public Health and Community Medicine, University of Washington.

[36] Grandjean, P., (1983), Occupational Health Aspects of Construction Work, Technical Report published by World Health Organization Regional Office for Europe, Copenhagen.

[37] International Labour office (2012), Safety, Health and Welfare on Construction Sites, Technical Report published by International Labour office Geneva. 